\title{
A content validity study of signs, symptoms and diseases/health problems expressed in LIBRAS ${ }^{1}$
}

\author{
Jamilly da Silva Aragão \\ Inacia Sátiro Xavier de França ${ }^{3}$ \\ Alexsandro Silva Coura ${ }^{3}$ \\ Francisco Stélio de Sousa ${ }^{3}$ \\ Joana D'arc Lyra Batista ${ }^{4}$ \\ Isabella Medeiros de Oliveira Magalhães ${ }^{5}$
}

Objectives: to validate the content of signs, symptoms and diseases/health problems expressed in LIBRAS for people with deafness Method: methodological development study, which involved 36 people with deafness and three LIBRAS specialists. The study was conducted in three stages: investigation of the signs, symptoms and diseases/health problems, referred to by people with deafness, reported in a questionnaire; video recordings of how people with deafness express, through LIBRA, the signs, symptoms and diseases/health problems; and validation of the contents of the recordings of the expressions by LIBRAS specialists. Data were processed in a spreadsheet and analyzed using univariate tables, with absolute frequencies and percentages. The validation results were analyzed using the Content Validity Index (CVI). Results: 33 expressions in LIBRAS, of signs, symptoms and diseases/health problems were evaluated, and 28 expressions obtained a satisfactory CVI (1.00). Conclusions: the signs, symptoms and diseases/health problems expressed in LIBRAS presented validity, in the study region, for health professionals, especially nurses, for use in the clinical anamnesis of the nursing consultation for people with deafness.

Descriptors: Deafness; Nursing; Validation Studies.

\footnotetext{
1 Supported by Universidade Estadual da Paraíba (UEPB), Brazil.

2 Master's student, Universidade Estadual da Paraíba, Campina Grande, PB, Brazil.

3 PhD, Professor, Departamento de Enfermagem, Universidade Estadual da Paraíba, Campina Grande, PB, Brazil.

${ }^{4}$ PhD, Professor, Centro de Ciências Biológicas e da Saúde, Universidade Federal de Campina Grande, Campina Grande, PB, Brazil.

5 Undergraduate student in Nursing, Universidade Estadual da Paraíba, Campina Grande, PB, Brazil. Scholarship holder from Conselho Nacional de Desenvolvimento Científico e Tecnológico (CNPq), Brazil.
}

Corresponding Author: Jamilly da Silva Aragão

Rua Manoel Alves de Oliveira, 159, BI. 13B, Apto. 204 Bairro: Catolé

CEP: 58410-575, Campina Grande, PB, Brasil

E-mail: jamilly_aragao@hotmail.com
Copyright () 2015 Revista Latino-Americana de Enfermagem This is an Open Access article distributed under the terms of the Creative Commons Attribution Non-Commercial License (CC BY-NC).

This license lets others distribute, remix, tweak, and build upon your work non-commercially, and although their new works must also acknowledge you and be non-commercial, they don't have to license their derivative works on the same terms. 


\section{Introduction}

For a long time people with deafness were considered to be ill, with limitations and cognitive deficits, stigmatized and the targets of prejudice. Currently, society understands these subjects as normal, with potential and abilities, making this a subject of interest of the scientific community ${ }^{(1)}$. However, despite deafness being one of the fastest growing sensory disabilities in Brazil and worldwide, this social group still faces many obstacles $^{(2)}$.

In Brazil accessibility to basic services is precarious for individuals with disabilities. The person with deafness presents greater difficulty interacting with society and impediments to health access; facing barriers because the health services lack trained professionals for correct and quality care through the use of Brazilian Sign Language (LIBRAS) ${ }^{(3)}$.

In this context, a study that aimed to characterize the perceptions of people with severe or profound deafness about the communication process in the health services, found that the deaf do not achieve effective communication in the healthcare area, experiencing negative feelings, due to a lack of the use of LIBRAS in communication with health professionals, requiring the presence of an interpreter ${ }^{(4)}$.

Originating from French Sign Language, LIBRAS is used by deaf communities and made up of phonological, morphological, syntactic and semantic linguistic levels. Each country has its sign language, according to the culture and regionalism. The difference between LIBRAS and the other languages is related to its visuospatial modality. Its use in Brazil is regulated by Law 10.436, of April 24, 2002, in which Article 2 recommends that the government and public service concessionary companies support the use and dissemination of LIBRAS. Article 3 states that the public service concessionary companies of healthcare should ensure care and treatment to people with deafness, according to the existing standards(5).

The lack of use of this linguistic speciality weakens the communication of people with deafness, as well as their access to the primary healthcare and hospital services offered by the Brazilian National Health System (SUS). The unpreparedness of the professionals affects the quality of the care and, consequently, the performance of appropriate treatment. It is essential that health professionals know LIBRAS, in order to comprehend people with deafness and not compromise the assistance provided ${ }^{(1,6)}$.
Since the 1990s, the training of professionals in the auditory health area has been the subject of research, however, authors state that literature is scarce. Considering the auditory health of the population, few studies have been performed on the validation of behavioral training programs for these professionals, after the introduction of the concepts of this area in their basic training(7).

Therefore, seeking to collaborate in the training of professionals and making them able to appropriately meet the basic needs of people with deafness, this study aimed to validate the content of signs, symptoms and diseases/health problems expressed in LIBRAS by people with deafness. Such expressions in LIBRAS may be used in the clinical anamnesis of the nursing practice, perfecting the work process and programs to improve the care for people with deafness, supporting new scientific productions in the area.

\section{Method}

This was a methodological development study, conducted between March 2012 and July 2013. Data collection took place at the Demósthenes Cunha Lima (EDAC) School of Audiocommunication, located in Campina Grande/Paraíba, Brazil. Validation of the content, which requires no statistical determination and is not expressed through a correlation coefficient, was chosen to be the start of the validation cycle. It is accomplished by questioning different experts, who highlight the objectives relevant for measuring and analyzing the representativity of the items that make up the object of analysis( ${ }^{(8)}$. In this investigation, the object analyzed was a set of expressions in LIBRAS, related to the signs, symptoms and diseases/health problems.

The study was conducted in three stages: I. Investigation of the signs, symptoms and diseases/ health problems, mentioned by people with deafness, reported in a questionnaire; II. Video recordings of how people with deafness expressed, through LIBRAS, the signs, symptoms and diseases/health problems; and III. Validation of the contents of the recordings of the expressions by experts in LIBRAS.

The sample consisted of 36 participants with deafness, recruited through at random from a population of 290 students enrolled in the school. The selection criteria were: to be 18 years of age or over, to have proficiency in LIBRAS and to be enrolled in the EDAC. 
For the judges, a sample of three experts was obtained by accessibility. The LIBRAS experts met the following inclusion criteria: to have Prolibras the proficiency exam which annually certifies LIBRAS teachers, translators and interpreters ${ }^{(9)}$ or to have completed a courses in LIBRAS; to have experience with LIBRAS; and to have ties with the EDAC. It was decided to invite an odd number of judges, avoiding dubious questions in the case of a tie(10). Next, the experts were personally invited by the researchers.

In stage I data were collected regarding the signs, symptoms and diseases/health problems present in the questionnaire, with the participant marking only what they did or did not present. In this stage the concept of the International Classification of Diseases and Related Health Problems(11) was considered. In Stage II the recording of the expressions in LIBRAS was carried out by two students at a scheduled day and time. After the recording was completed the team met with the other participants for presentation of the images. At this moment, all the participants filled out a form, agreeing or not that the recordings represented the signs in LIBRAS expressed and used by them.

Then the records were submitted to the LIBRAS experts for consideration. The evaluation instrument used by the experts was a Likert type scale, adapted for this study, consisting of 33 items, containing signs, symptoms and diseases/health problems reported by people with deafness. The scale contained the items 1-Very Bad and 2-Bad: not relevant or not representative; 3-Regular: item needs major revision to be representative; 4-Good: item needs slight revision to be representative; 5-Excellent: item relevant or representative. Thus, the experts marked an $X$ on the scale to score the images, according to their understanding of similarity between the image and text. The experts used the following criteria for the evaluation of the LIBRAS images: expression, comprehension and precision of the expressions.

Data were processed in an Excel spreadsheet and analyzed using univariate tables, with absolute frequencies and percentages. The validation results were analyzed using the Content Validity Index $(\mathrm{CVI})^{(8)}$, which measures the proportion or percentage of judges who agree on determined aspects of the instrument and its items. The items marked with "Good" or "Excellent" were considered to be representative, receiving an index score of 1.00 : $100 \%$ agreement.
The design of this study was approved by the Research Ethics Committee of the State University of Paraíba, with Plataforma Brasil registration (CAAE No. 0700.0.133.000-11). Each participant was informed about who the researchers were, the aims and benefits of the study, the guarantee of confidentiality and privacy of the information and the right to withdraw from the research, without any repercussions, at any time. The Informed Consent Terms were presented and then the subjects who met the study inclusion criteria signed the Informed Consent form, as recommended by Resolution $466 / 12$ of the National Health Council.

Regarding the image recording for the expression in LIBRAS of the signs, symptoms and diseases/health problems, the participants were informed about the video recording of the images resulting from the collection, these being for the exclusive use of the project. They signed the document, allowing the reproduction of the images and their use in public.

\section{Results}

The study included 36 subjects aged between 18 and 35 years, with the majority being 18 to 23 years of age $(55.6 \%)$, males $(63.9 \%)$, single $(83.3 \%)$ and with income between one and two minimum wages (75\%).

Through the questionnaire data related to stage I it was possible to identify the health problems reported by the participants and their prevalence, as described in Table 1 . In their daily lives, the participants predominantly reported: intense thirst $(83.3 \%)$, headache $(80.6 \%)$, toothache $(69.4 \%)$, cough $(66.7 \%)$, vomiting $(55.6 \%)$, diarrhea $(50.0 \%)$ and fever $(50.0 \%)$.

The recordings of the LIBRAS expressions are presented in Figure 1 (signs), Figure 2 (symptoms) and Figure 3 (diseases/health problems).

Regarding the evaluation by the participants with deafness of the expressions of the signs, symptoms and diseases/health problems, made by two students in the recordings of the images, $100 \%$ agreed that they were represented with the same linguistic signs presented in the images.

As shown in Table 2, after the evaluation of the experts of the 33 LIBRAS expressions referring to signs, symptoms and diseases/health problems, 28 expressions were representative and considered valid. The images evaluated as representative obtained CVI $=1.00 ; 100 \%$ positive response and $\geq 0.80$ overall CVI. The other images with lower CVIs were excluded, as detailed below. 
Table 1 - Distribution of people with deafness, according to the occurrence of signs, symptoms and health problems. Campina Grande, PB, Brazil, 2012

\begin{tabular}{|c|c|c|}
\hline Signs, symptoms and diseases/health problems & $\mathbf{N}$ & $\%$ \\
\hline \multicolumn{3}{|l|}{ Signs } \\
\hline Cough & 24 & 66.7 \\
\hline Fever & 18 & 50.0 \\
\hline Flu & 15 & 41.7 \\
\hline Flaccid stomach & 14 & 38.9 \\
\hline Difficulty breathing & 14 & 38.9 \\
\hline Hoarseness & 14 & 38.9 \\
\hline High pressure & 7 & 19.4 \\
\hline Low pressure & 5 & 13.9 \\
\hline Hyperglycemia & 4 & 11.1 \\
\hline \multicolumn{3}{|l|}{ Symptoms } \\
\hline Intense thirst & 30 & 83.3 \\
\hline Headache & 29 & 80.6 \\
\hline Toothache & 25 & 69.4 \\
\hline Vomiting & 20 & 55.6 \\
\hline Diarrhea & 18 & 50.0 \\
\hline Stomach pain & 17 & 47.2 \\
\hline Chest pain & 16 & 44.4 \\
\hline Pain & 15 & 41.7 \\
\hline Shivering/chills & 14 & 38.9 \\
\hline Heartburn & 12 & 33.3 \\
\hline Difficulty urinating & 11 & 30.6 \\
\hline Lack of appetite & 10 & 27.8 \\
\hline Stomach ache & 9 & 25.0 \\
\hline Difficulty to evacuate & 8 & 22.2 \\
\hline Urine elimination (high quantity) & 8 & 22.2 \\
\hline Uncontrolled urination & 5 & 13.9 \\
\hline Uncontrolled bowel & 4 & 11.1 \\
\hline Back pain & 2 & 5.6 \\
\hline Palpitations & 1 & 2.8 \\
\hline \multicolumn{3}{|l|}{ Diseases/health problems } \\
\hline Anemia & 11 & 30.6 \\
\hline Kidney stone & 6 & 16.7 \\
\hline Sexual alteration & 2 & 5.6 \\
\hline Fertility alteration & 1 & 2.8 \\
\hline
\end{tabular}




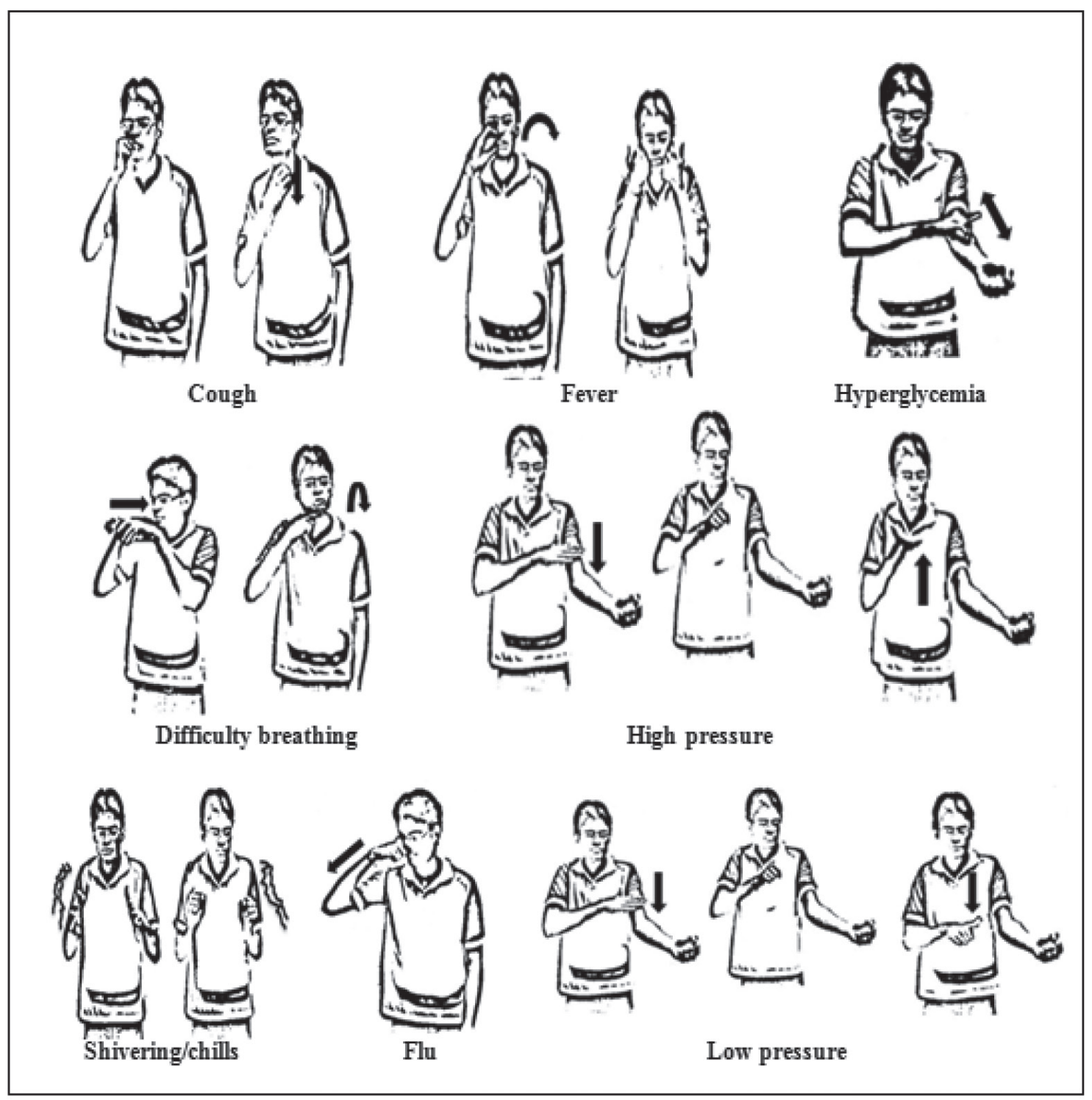

Figure 1 - LIBRAS expression by people with deafness for signs of health problems. Campina Grande, PB, Brazil, 2012 


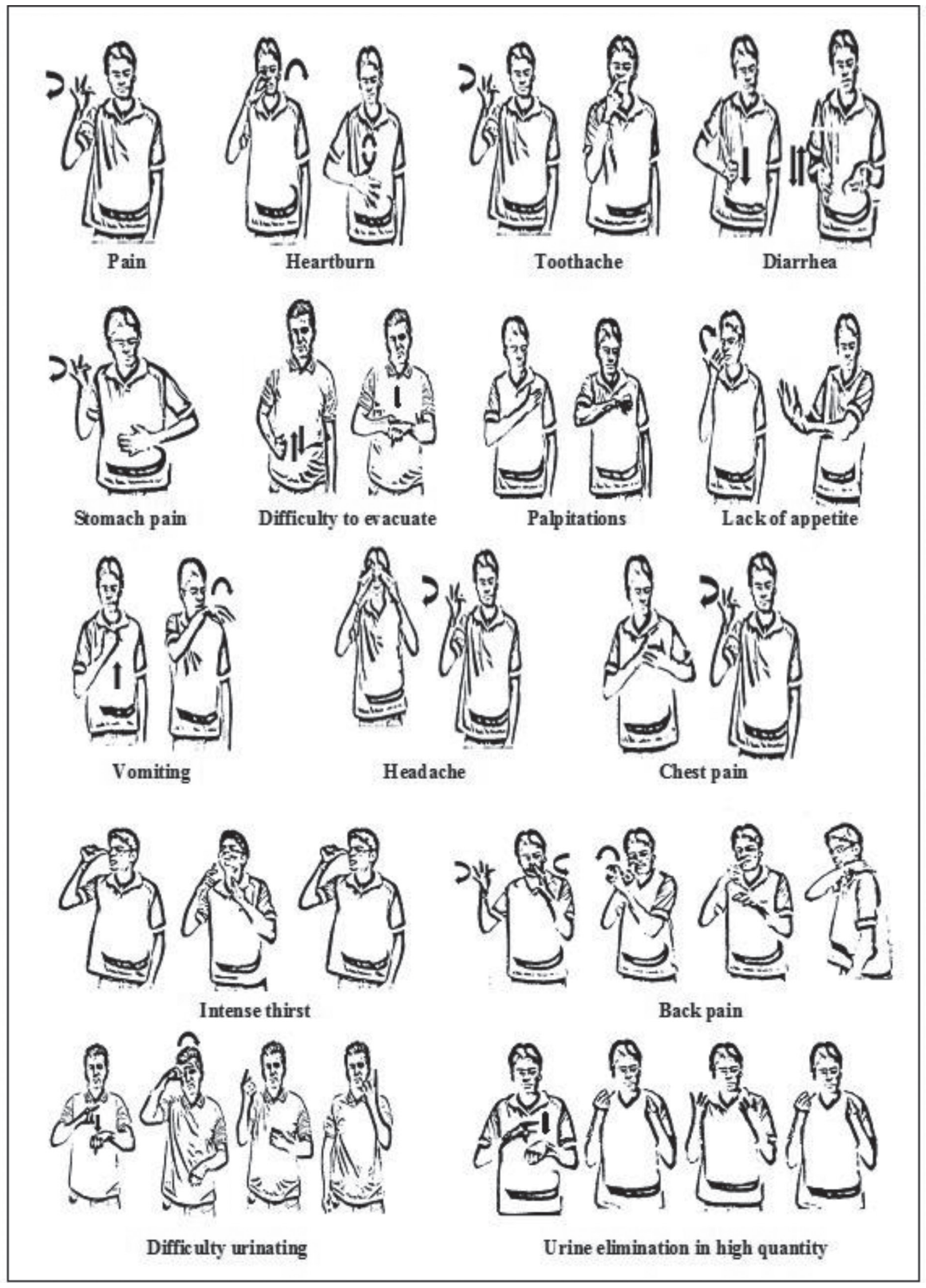

Figure 2 - LIBRAS expression by people with deafness for symptoms of health problems. Campina Grande, PB, Brazil, 2012 


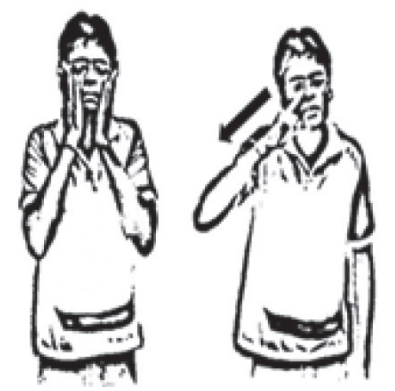

Anemia

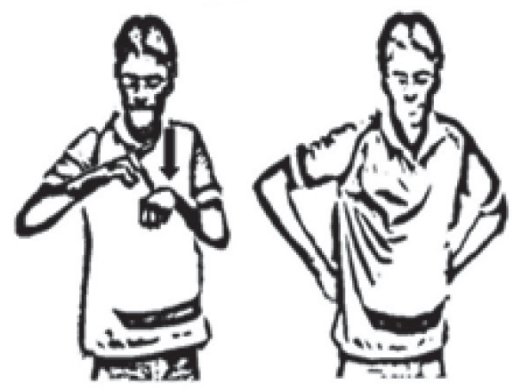

Kidney stone

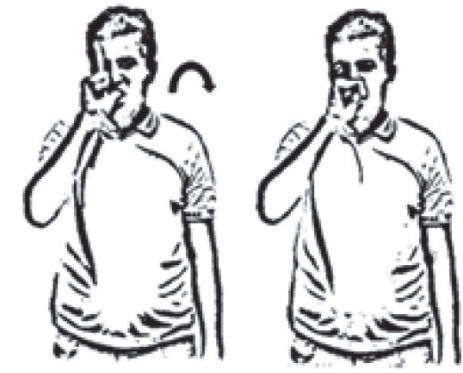

Sexual alteration $(\mathrm{M})^{*}$
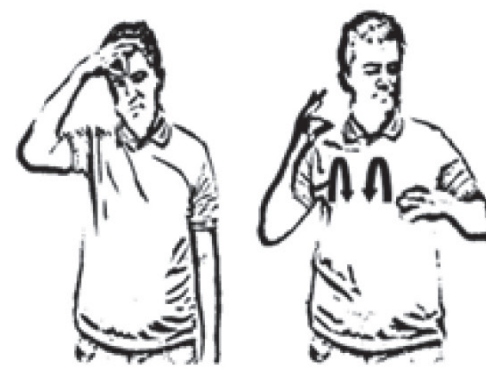

Sexual alteration (W)*

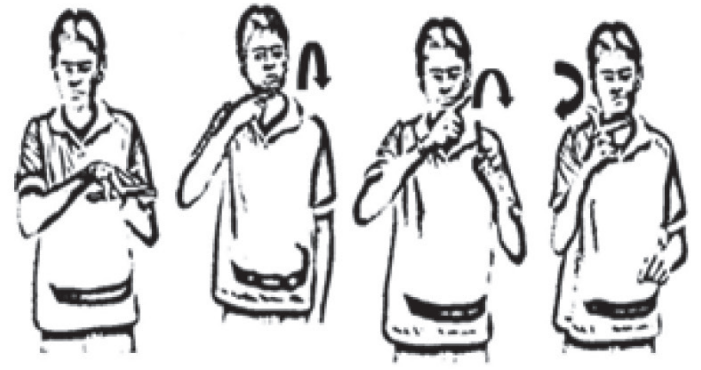

Fertility alteration

Figure 3 - LIBRAS expression by people with deafness for diseases/health problems. Campina Grande, PB, Brazil, 2012

* (M) Men; (W) Women

Table 2 - Distribution of Content Validity Index (CVI), according to the signs, symptoms and diseases/health problems expressed in LIBRAS. Campina Grande, PB, Brazil, 2012

\begin{tabular}{|c|c|c|c|c|c|}
\hline \multirow{2}{*}{ Signs, symptoms and diseases/health problems } & \multicolumn{2}{|c|}{$\mathrm{CVI}^{*} /$ Student ${ }^{\dagger}$} & \multirow{2}{*}{$\mathrm{CVI}^{*}$} & \multirow{2}{*}{$(\%)$} & \multirow{2}{*}{ Overall CVI' } \\
\hline & 1 & 2 & & & \\
\hline \multicolumn{6}{|l|}{ Signs } \\
\hline High pressure & 1.00 & 1.00 & 1.00 & 100 & 0.84 \\
\hline Low pressure & 1.00 & 1.00 & 1.00 & 100 & \\
\hline Hyperglycemia & 1.00 & 1.00 & 1.00 & 100 & \\
\hline Flaccid stomach & 0.67 & 0.67 & 0.67 & 67 & \\
\hline Cough & 1.00 & 1.00 & 1.00 & 100 & \\
\hline Hoarseness & 0.67 & 0.67 & 0.67 & 67 & \\
\hline Fever & 1.00 & 1.00 & 1.00 & 100 & \\
\hline Difficulty breathing & 1.00 & 1.00 & 1.00 & 100 & \\
\hline Flu & 1.00 & 1.00 & 1.00 & 100 & \\
\hline \multicolumn{6}{|l|}{ Symptoms } \\
\hline Difficulty to evacuate & 1.00 & 1.00 & 1.00 & 100 & \\
\hline Difficulty urinating & 0.67 & 1.00 & 1.00 & 100 & \\
\hline Uncontrolled intestinal elimination & 0.67 & 0.67 & 0.67 & 67 & \\
\hline Uncontrolled urinary elimination & 0.67 & 0.67 & 0.67 & 67 & \\
\hline Pain & 1.00 & 1.00 & 1.00 & 100 & \\
\hline Stomach pain & 0.67 & 0.67 & 0.67 & 67 & \\
\hline Back pain & 1.00 & 1.00 & 1.00 & 100 & \\
\hline Heartburn & 1.00 & 1.00 & 1.00 & 100 & \\
\hline Vomit & 1.00 & 1.00 & 1.00 & 100 & \\
\hline
\end{tabular}


Table 2 - (continuation)

\begin{tabular}{|c|c|c|c|c|c|}
\hline \multirow{2}{*}{ Signs, symptoms and diseases/health problems } & \multicolumn{2}{|c|}{$\mathrm{CVI}^{\star} /$ Student ${ }^{\dagger}$} & \multirow{2}{*}{$C V I^{*}$} & \multirow{2}{*}{$(\%)$} & \multirow{2}{*}{ Overall CVI } \\
\hline & 1 & 2 & & & \\
\hline Diarrhea & 1.00 & 1.00 & 1.00 & 100 & \\
\hline Toothache & 1.00 & 1.00 & 1.00 & 100 & \\
\hline Stomach pain & 1.00 & 1.00 & 1.00 & 100 & \\
\hline Headache & 1.00 & 1.00 & 1.00 & 100 & \\
\hline Chest pain & 1.00 & 1.00 & 1.00 & 100 & \\
\hline Urine elimination in high quantity & 1.00 & 1.00 & 1.00 & 100 & \\
\hline Intense thirst & 1.00 & 1.00 & 1.00 & 100 & \\
\hline Shivering/chills & 1.00 & 1.00 & 1.00 & 100 & \\
\hline Lack of appetite & 1.00 & 1.00 & 1.00 & 100 & \\
\hline Palpitations & 1.00 & 1.00 & 1.00 & 100 & \\
\hline \multicolumn{6}{|l|}{ Diseases/health problems } \\
\hline Anemia & 1.00 & 1.00 & 1.00 & 100 & \\
\hline Sexual alteration in men & 0.67 & 1.00 & 1.00 & 100 & \\
\hline Sexual alteration in women & 0.67 & 1.00 & 1.00 & 100 & \\
\hline Fertility alteration & 1.00 & 1.00 & 1.00 & 100 & \\
\hline Kidney stone & 1.00 & 0.33 & 1.00 & 100 & \\
\hline
\end{tabular}

*Content Validity Index.

†Agreement among the experts with the expressions of students 1 and 2 .

\section{Discussion}

The socio-demographic profile identified is consistent with the literature, indicating that the majority of the participants were men, without partners and with low monthly income(12-14).

No studies that used a similar method to this research to verify signs, symptoms and diseases/health problems referred to by people with deafness were identified, hindering further comparison of data generated. However, some data are worrying, as they may indicate health problems, such as diabetes, considering that a significant number of subjects reported having had high blood glucose levels. One study with people with deafness found that $11.1 \%$ presented altered glucose levels ${ }^{(15)}$.

In addition, many signs and symptoms listed may suggest life habits with the risk of the development of diseases, with it being important to correctly identify the linguistic signs in LIBRAS. Therefore, the study sought to validate the content of LIBRAS expressions, about signs, symptoms and diseases/health problems of people with deafness, to guide professionals regarding knowledge in LIBRAS, in order to facilitate communication and improve the provision of healthcare. Another study found that the difficulty of access to health services for people with deafness is related directly with communication, suggesting the need for studies on the topic ${ }^{(4)}$.

LIBRAS is still not commonly used in healthcare, because studies have shown a lack of teaching of the language in Higher Education Institutions (HEIs). Decree No. 5.626 of December 22, 2005, however, which states that LIBRAS must be included as a mandatory or optional curriculum subject in higher-level courses and professional education of public and private education institutions, from the year of its publication ${ }^{(16)}$.

It is considered that an instrument, technology and/ or tool may have its content validated by a scientific study, with the assessment of experts in the area of inclusion of the product developed(17). From this perspective, the validation achieved through the research protocol of this study and its results, with the participation of 36 subjects with deafness, three specialists and the researchers, makes the expressions of signs, symptoms and diseases/health problems in LIBRAS valid for communication among health professionals and people with deafness in the city of Campina Grande/PB, Brazil.

The legitimacy of a positive assessment by experts is strengthened by satisfactory CVI values, according to the literature ${ }^{(18)}$. However, this validity is restricted to the participant population and can be temporary, considering that LIBRAS evolves and presents regional differences. It should also be noted that despite the limitation of the CVI, based on small numbers of experts and subjects, the study developed is an indication that LIBRAS is a good clinical anamnesis instrument for the evaluation of people with deafness.

Other studies have validated transcripts of instruments and questionnaires for sign languages. 
A British study translated three clinical evaluation instruments (Patient Health Questionnaire (PHQ-9), Generalized Anxiety Disorder 7-item (GAD-7) scale, Work and Social Adjustment Scale- WSAS) into British Sign Language (BSL), this being the sign language of the country(19).

Another study, conducted by Brazilian researchers, constructed and validated LIBRAS versions of the WHOQOL-BREF and WHOQOL-DIS instruments, to evaluate the quality of life of the Brazilian population with deafness. These validations have the potential to optimize the accessibility of people with deafness, including participation in research projects and their access to information(20).

It is important to indicate the potential of the validation developed in this study, which can be understood as focusing on three dimensions: optimization of communication, guarantee of confidentiality/ privacy and qualifications of the healthcare. Regarding communication, it is believed that with the existence of signs, symptoms and diseases/health problems validated and known by health workers, the emission and reception of the communicative signs will be better understood among the subjects. Studies with nursing professionals demonstrate difficult communication due to the lack of understanding and signing of LIBRAS(21-22).

In another study concerning people with deafness, LIBRAS was the preferred language, however, some reported using other forms of communication, depending on the communicative need, especially with regard to the listeners ${ }^{(23)}$. Communication alternatives, such as mimes, help from family members and interpreters, make it difficult to guarantee the ethical right to confidentiality and privacy of information provided by patients with deafness. In this context, another dimension of the advantages of the validation developed in this study is indicated, as with well-defined signs, dialogue between professionals and the person with deafness is preserved.

Furthermore, the qualification of healthcare appears as an advantage of the validation of this study, and another advance for the inclusion of people with deafness in health services, promoting equity of care, as the lack of friendly communication is what often prevents them seeking and using basic services ${ }^{(4)}$. As with this study, another study found the need to study LIBRAS in order to change the attitudes of professionals regarding the care provided to people with deafness and their family members, optimizing the professional practice in healthcare ${ }^{(3)}$
The LIBRAS expressions relating to the signs, symptoms and diseases/health problems appear to be validated, however five of them did not meet the acceptance threshold by the experts, i.e. they were not representative, because they did not fulfill the criteria expression, comprehension and precision of the signs, according to the experts. Therefore, these signs must be targets for improvement in further studies.

\section{Conclusions}

The signs, symptoms and diseases/health problems expressed in LIBRAS presented validity, in the study region, for health professionals, especially nurses, for use in the clinical anamnesis of the nursing consultation for people with deafness, reducing the barriers of communication and strengthening the professionalperson with deafness dyad, indispensable for healthcare.

The validation coming from this study, with the participation of experts, is relevant, presenting reliability of use. Due to LIBRAS undergoing changes with time, as well as being different among regions and heterogeneous groups of the same region, for the use in the clinical anamnesis of patients with deafness it is necessary that it go through other levels of validation, with different medical specialties, and in regional and national contexts.

\section{References}

1. Pereira LAC, Corrêa CS, Barreto LS, Celestino PPF, André KM. Bringing awareness to nurses in relation to patients with hearing loss. Rev Pesqui Cuid Fundam. 2010;2(2):758-69.

2. Vianna NG, Cavalcanti MLT, Acioli MD. Princípios de universalidade, integralidade e equidade em um serviço de atenção à saúde auditiva. Ciênc Saúde Coletiva. 2014;19(7):2179-88.

3. Souza MT, Porrozzi R. Ensino de Libras para os Profissionais de Saúde: Uma Necessidade Premente. Rev Práxis. 2009;1(2):43-6.

4. Cardoso AHA, Rodrigues KG, Bachion MM. Perception of persons with severe or profound deafness about the communication process during health care. Rev. LatinoAm. Enfermagem. 2006;14(4):553-60.

5. Ministério da Educação e Cultura (BR). Parâmetros curriculares nacionais: adaptações curriculares em ação - estratégias para educação de alunos com necessidades educacionais especiais. Brasília: Ministério da Educação e Cultura; 2002. 
6. Ianni A, Pereira PCA. Acesso da Comunidade Surda à Rede Básica de Saúde. Saúde Soc. 2009;18(2):89-92.

7. Melo TM, Alvarenga KF. Capacitação de profissionais da saúde na área de saúde auditiva: revisão sistemática. Rev Soc Bras Fonoaudiol. 2009;14(2):280-6.

8. Alexandre NMC, Coluci MZO. Validade de conteúdo nos processos de construção e adaptação de instrumentos de medidas. Ciênc Saúde Coletiva. 2011;16(7):3061-8.

9. Faria JG. Formação, profissionalização e valorização do professor surdo: reflexões a partir do Decreto 5.626/2005. Rev Bras Educ Espec. 2011;17(1):87-100. 10. Lobão WM, Menezes IG. Construction and content validation of the scale of predisposition to the occurrence of adverse events. Rev. Latino-Am. Enfermagem. 2012;20(4):796-803.

11. Togna GRD, Crosato E, Melani RFH, Michel-Crosato E, Biazevic MGH. Uso da Classificação Internacional de Doenças na análise do absenteísmo odontológico. Rev Saúde Pública. 2011;45(3):512-8.

12. Francelin MAS, Motti TFG, Morita I. As implicações sociais da deficiência auditiva adquirida em adultos. Saúde Soc. 2010;19(1):180-92.

13. Shuaib AK, Olushola AA, Biodun SA, Isiah OE. Epidemilogical profile of speech and language disorder in north central Nigeria. Int J Biomed Sci. $2011 ; 7(4): 268-72$.

14. Bittencourt ZZLC, Hoehne EL. Qualidade de vida de familiares de pessoas surdas atendidas em um centro de reabilitação. Ciênc Saúde Coletiva. 2009;14(4):1235-9. 15. França ISX, Aragão JS, Coura AS, Vieira CENK, Silva JF, Cruz GKP. A relação entre atividades de lazer e níveis glicêmicos de adultos surdos. Rev RENE. 2013;14(6):1193-200.

16. Oliveira YCA, Costa GMC, Coura AS, Cartaxo RO, França ISX. A língua brasileira de sinais na formação dos profissionais de enfermagem, fisioterapia e odontologia no estado da Paraíba, Brasil. Interface comum. Saúde educ. $2012 ; 16(43)$ :995-1008.

17. Amendola F, Alvarenga MRM, Gaspar JC, Yamashita $\mathrm{CH}$, Oliveira MAC. Validade aparente de um índice de vulnerabilidade das famílias a incapacidade e dependência. Rev Esc Enferm USP. 2011;45(2):1736-42. 18. Alexandre NMC, Coluci MZO. Validade de conteúdo nos processos de construção e adaptação de instrumentos de medidas. Ciênc Saúde Coletiva. 2011;16(7):3061-8. 19. Rogers KD, Young A, Lovell K, Campbell M, Scott $\mathrm{RP}$, Kendal $\mathrm{S}$. The British Sign Language Versions of the Patient Health Questionnaire, the Generalized Anxiety Disorder 7-Item Scale, and the Work and Social Adjustment Scale. Oxford J. 2012;18(1):110-22.
20. Chaveiro N, Duarte SBR, Freitas AR, Barbosa MA, Porto CC, Fleck MPA. Instrumentos em Língua Brasileira de Sinais parágrafo Avaliação da Qualidade de Vida da População surda. Rev Saúde Pública. 2013;47(3):616-23. 21. Chaveiro N, Barbosa MA, Portoc C, Munari DB, Medeiros $M$, Duarte SBR. Atendimento à pessoa surda que utiliza a língua de sinais, na perspectiva do profissional da saúde. Cogitare Enferm. 2010;15(4):639-45.

22. Machado WCA, Machado DA, Figueiredo NMA, Tonini T, Miranda RS, Oliveira GMB. Sign language: how the nursing staff interacts to take care of deaf patients? J Res: Fundam Care. 2013;5(3):283-92.

23. Lopes MAC, Leite LP. Concepções de surdez: a visão do surdo que se comunica em língua de sinais. Rev Bras Educ Espec. 2011;17(2):305-20. 